The Geographical Journal of Nepal

Vol. 11: 113-126, 2018

Central Department of Geography,

Tribhuvan University, Kathmandu, Nepal

\title{
Diversification of livelihood strategies in Melamchi valley, Sindhupalchok district, Nepal
}

\author{
Madhu Krishna Neupane; and Dhyanendra Bahadur Rai* \\ Central Department of Geography, Tribhuvan University, Kathmandu, Nepal \\ (*Corresponding Author:dbrrai@yahoo.com)
}

Livelihood strategy varies from place to place. People living in certain place have a diverse strategy over time. This study attempts to analyze the sources of livelihood, livelihood strategies of different communities and their adaptive strategies in Melamchi Valley. The livelihood patterns and the strategies have been dealt on the basis of community. This study is based on primary data that are collected using household questionnaire, focus group discussion and key informant interview. A set of standardized questionnaire, observation sheet, and checklist were used for information collection. The finding of the study portrays that paddy is the major crop cultivated by Brahmin/Kshetri communities whereas millet and maize are the principal crops cultivated by Tamang community. People of this area are attracted towards cash generating activities than the subsistence agriculture farming in the present days. The people of market center are motivated towards trade and business whereas the people of remote area have dependence on remittance. The trend of foreign migration for earning livelihood is high among the rural settlements. Similarly, earning from wage labor in the informal sectors has become important source of livelihood in Melamchi Valley.

Keywords: Livelihood strategies; diversified livelihood; Melamchi Valley; rural livelihoods

\section{Introduction}

The livelihood, in its simplest sense; is a means of gaining living (Ellis, 2000). According to Chamber and Conway (1992), a livelihood comprises the capabilities assets (resources, stores, claims and access) and activities required for a means of living and a livelihood is sustainable when it can cope with and provide sustainable livelihood opportunities for the next generation. Livelihood strategies are the range and combination 
of different activities and choices of individuals or households in order to achieve their livelihood needs. Livelihood strategies operate both at household and individual levels, either through continuity or modification of economic and social activities in order to meet the basic needs for survival and existence. Some people continue their traditional occupations and activities while others modify their strategies. Several internal and external factors impinge up on the livelihood strategies of the people (Chhetri, 2006).

People have adjusted their ways of earning livelihood to the changing environment from historical times. Their livelihood strategies to adapt to the changing environment condition differ over spaces and by social groups; cultural values of people in the same space can create differences in the pattern of adaptation from one ethnic group to another (Subedi and Pandey, 2002). Various studies done in the rural hilly and mountain areas have observed that livelihood strategies of people are shifting from agriculture to nonagriculture based livelihoods such as wage labor, business, petty business, vegetable farming and foreign labor migration (Koirala, 2006; Rai, 2009; Khatiwada, 2010; Rai, 2011). People in the high Himalayas pursue different types of livelihood activity for adaptation. Bishop (1997) points out that people in the rural Nepalese hill region can achieve subsistence only by some combination of six different livelihood pursuits such as agriculture, animal husbandry, exploitation of the wild bio-diversity, trade and seasonal out migration for work. The importance of these components varied among households or villagers in different micro-regions. The present study is an attempt for the examination of livelihood in mountain community of Melamchi Valley in the central Nepal.

\section{Methods and materials}

The results and discussion in this paper is mainly based on primary data, collected from the field by applying various field techniques and instruments i.e. household questionnaire survey, focus group discussion, field observation, and key informant interview. Before moving to individual houses for data collection, the households were selected by random sampling methods and of the total 4480 household from four VDCs of Melamchi Valley, 202 households were selected in equal proportion for the survey. The proportion of caste and ethnicity were also considered for selecting sampled household. A standardized questionnaire was prepared for the household survey which included the information of demography, education, occupation, land holding/ use, family income/expenditure, assets, living condition etc. Observation was done to validate the information provided by the respondents. Key informant interview (KII) and focus group discussion (FGD) were carried out systematically in all settlements to cover the issues not dealt in questionnaire as well as to verify the data collected from 
questionnaire survey. Basically, the information about diversified livelihood strategies and adaptive strategies were captured from KII and FGD. Eight KII (two from each VDC) and four (one from each VDC) FGD were conducted. Participants of KII and FGD represent different sectors of people i.e. sex, caste/ethnicity, occupation, age and education. There were six to seven persons in each FGD. Long and open interview were taken with key informants (Neupane, 2017).

\section{Study area}

The area selected for the research is Melamchi Valley located in central mountain region in Sindhupalchok district. The district is situated $85 \mathrm{~km}$ north east of capital city Kathmandu on the lap of Jugal Himalayan Range. The study area includes Melamchi, Ichok, Duwachour and Helambu VDCs of Melamchi River Basin. The location of the study area is shown in Figure 1.

Melamchi watershed area contains from High Mountain covered with snow in northern part, to hill slope with terraces in mid-hill and river valleys and river terraces in southern belt. Melamchi River flows from Helambu to down south, Ichok has east facing slope towards the river whereas Duwachour faces west south slope in direction to Melamchi River. The climate of this

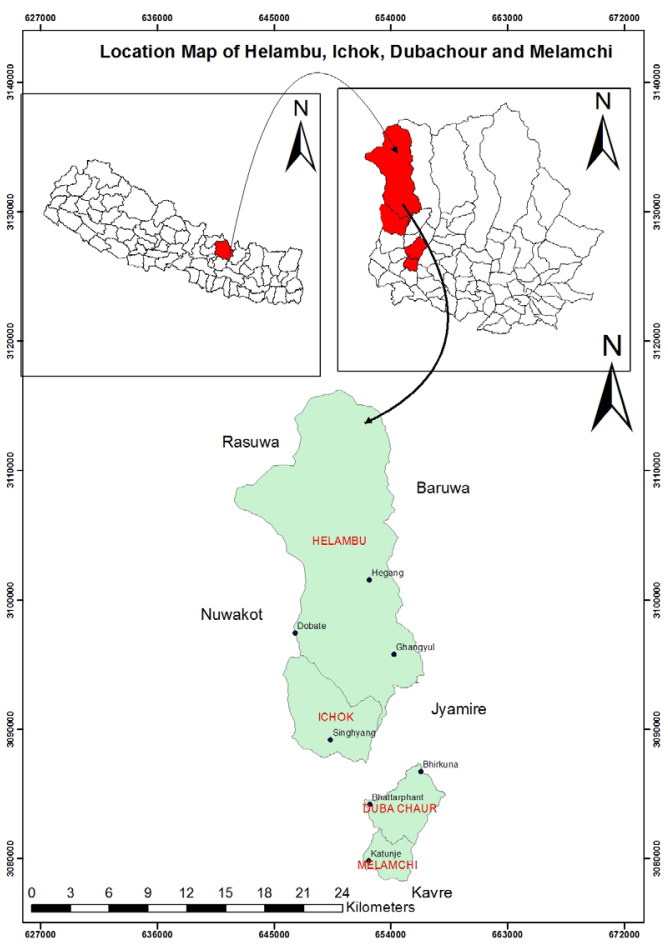

Figure 1: Location of the study area area can be divided into four types i.e. Tundra, Alpine, Cool Temperate and Warm Temperate. However, most part of the area experience cool climate. The area receives rainfall mainly in monsoon seasons from June to August. The major ten castes and ethnicities residing in the study area include Tamang (34.25\%), Kshetri (18.23\%), Newar (11.11\%), Brahmin (10.33\%), Kami (3.88\%), Sannyasi/Dasnami (3.62\%), Sherpa (2.63\%), Majhi (2.29\%), Damai (1.90\%) and Magar $(1.71 \%)$. The major road Melamchi to Helambu plays important role for the access of people in this area. 


\section{Livelihood strategies in Melamchi valley}

\section{Livelihood dependence on agriculture}

The basic characteristic of rural livelihood is high dependency on agricultural activities. Each member of the household supports the agriculture work in one way or other. During the planting and harvesting season of major crops, the number of labor force involved in is high and so is the time and money. In this scenario, workable member of the house and the neighbors from the village are labor force in the field. Here, neighbors involved in agriculture are not necessarily paid in monetary unit instead the host household members should pay back the labor force work participating in similar nature of work in guest's household on given day, locally known as parma. Parma system is also commonly practiced from the very beginning in this area. It is easy and accessible because of agglomerated settlements of particular community in a village. This system is still popular in the village. It requires no money for laboring but exchange labor among each other within community. Furthermore, it has become essential because of lacking agricultural human power in those days. If not so, farming is impossible in the village. Major agricultural works such as planting, weeding and harvesting are accomplished with this system because those items require more human power. After completing major works of farming, male member of the household usually go outside of home for earning cash as wage labor.

High dependency on agriculture means, there is very less or not any income generation source besides it. In order to fulfill the ever growing demand of the family, people have to work throughout the year in the field and feeding livestock, so people do not have a work leave as in other service sectors.

Table1:Ways of earning livelihood

\begin{tabular}{|l|r|r|r|r|r|}
\hline Job/Occupation & Melamchi & Ichok & Duwachour & Helambu & Total \\
\hline Farmer & 75 & 102 & 123 & 83 & 383 \\
\hline Worker & 6 & 7 & 15 & 16 & 44 \\
\hline Private Business & 36 & 9 & 9 & 7 & 61 \\
\hline Service & 17 & 8 & 5 & 1 & 31 \\
\hline Others & 19 & 13 & 12 & 26 & 70 \\
\hline Total & 163 & 139 & 164 & 133 & 589 \\
\hline
\end{tabular}

Source: Field Survey, 2014 
Most of the people (65 percent) involve in agriculture out number the people engaged in other activities in Melamchi Valley (Table 1). Generally, people cultivate the crops that they consume. However, the diversity of crops produced depends upon the land size, elevation and availability of irrigation facility. Major cereal crops of this valley are paddy, maize, wheat, and millet. Similarly, potato, green vegetables, mustard, ginger, cardamom and apple are main cash crops in this area. In addition to household consumption, the surplus food grain is sold in the village or market center. Cash income is generated from potato farming, vegetable farming and production of cash crops apart from the cereal crops.

\section{Agricultural land: The major physical capital}

In rural agrarian economy like that of Nepal, land has traditionally been primary source of livelihood and household security, as well as a symbol of status (Sharma et al., 2014). A household is economically stable and secure if it has some land. The common belief is held, there are no other source of income except for the land which are assets that are permanent and can assure security for the current generation as well as for the future. Every other source of livelihood is temporary and has no guarantee for the future. The importance of land is illustrated by the expression such as uttamkheti, madhyambyapar, adhamjagir (agriculture is superior, business is medium and service is the inferior) (Subedi, 1993).

Land is the major assets people want to invest and own in rural area. Melamchi Valley is no exception in this regard. Holding large area of khet (irrigated land) has higher social and economic value in the village. Basically, people's status is determined by the land they are possessing. It is due to opportunity to cultivate multiple crops and in large volume which eventually gives high returns. Table 2 shows that 39 percent of household has 3 to 11 ropani of land in the valley area. In total 18 percent owns more than 16 ropani of land. Similarly, 5 percent does not have any of the agricultural land for cultivation particularly. The people of Melamchi bazar have sizable number who are engaged in different income generating activities other than agriculture. 
Tble2:Land holding in Ropani ( 1 ropani $=508.74 \mathrm{sq} \mathrm{m}$ )

\begin{tabular}{|c|c|c|c|c|c|c|c|}
\hline VDC & Category & $\begin{array}{r}\text { Without } \\
\text { land }\end{array}$ & $\begin{array}{r}\text { Less } \\
\text { than } 3\end{array}$ & 3 to 7 & $\begin{array}{r}8 \text { to } \\
11\end{array}$ & 12 to 15 & 16 above \\
\hline \multirow{4}{*}{ Melamchi } & Bari & 15 & 6 & 15 & 6 & 3 & 4 \\
\hline & Khetland & 7 & 4 & 21 & 7 & 4 & 6 \\
\hline & Total & 7 & 1 & 13 & 7 & 8 & 13 \\
\hline & Percent & 14 & 2 & 27 & 14 & 16 & 27 \\
\hline \multirow{4}{*}{ Duwachour } & Bari & 2 & 13 & 30 & 5 & 2 & 0 \\
\hline & Khetland & 3 & 6 & 30 & 5 & 6 & 2 \\
\hline & Total & 1 & 1 & 18 & 14 & 8 & 10 \\
\hline & Percent & 2 & 2 & 35 & 27 & 15 & 19 \\
\hline & Bari & 6 & 17 & 26 & 0 & 1 & 0 \\
\hline & Khetland & 2 & 14 & 22 & 7 & 2 & 3 \\
\hline & Total & 2 & 1 & 21 & 12 & 9 & 5 \\
\hline & Percent & 4 & 2 & 42 & 24 & 18 & 10 \\
\hline & Bari & 2 & 8 & 28 & 6 & 3 & 4 \\
\hline & Khetland & 28 & 3 & 13 & 3 & 2 & 2 \\
\hline & Total & 1 & 3 & 27 & 8 & 4 & 8 \\
\hline & Percent & 2 & 6 & 53 & 16 & 8 & 16 \\
\hline \multicolumn{2}{|l|}{ Grand Total } & 11 & 6 & 79 & 41 & 29 & 36 \\
\hline \multicolumn{2}{|l|}{ Grand Percent } & 5 & 3 & 39 & 20 & 14 & 18 \\
\hline
\end{tabular}

Source: Field survey, 2014

However, considering the household exclusively holding khet, 20 percent of the 202 household does not have irrigated land while 54 percent own 3 to 11 ropani of land and only 6 percent have above 16 ropani of khet. Household having kharbari (grass land) is of least numbers so it is not included in Table 2. So far as, the landholding of the households in Melamchi Valley is concerned most of the farmers have small land holding size.

\section{Crop production}

The dominant crop produced in Melamchi Valley is cereal. The total of 336 metric ton of cereal crops were produced in surveyed household. Where, paddy was the leading crop produced with 47 percent of the total production followed by maize 24 percent, millet 18 percent and wheat 10 percent (Table 3). Although, paddy is the major cereal crops to be cultivated, 26 percent of household produces less than $100 \mathrm{~kg}$. Similarly, 46 percent of household produces between 101 to $1000 \mathrm{~kg}$ of paddy. Only a few (8 percent) household produces more than $2000 \mathrm{~kg}$. Other cereal crops also have similar 
figure. Likewise, 50 percent of household produces below $100 \mathrm{~kg}$ of wheat and for maize and millet 28 percent of household produces less than $100 \mathrm{~kg}$. Going further to the VDC level, total of 160 metric ton paddy was produced. Melamchi and Ichok VDC contributed 73 percent of the total paddy production whereas Duwachor and Helambu added 27 percent. With steep slope and elevation Helambu made only 4 percent of total paddy production.

Table 3: Cereal crop production in Melamchi Valley

\begin{tabular}{|l|r|r|r|r|r|r|r|r|}
\hline \multirow{2}{*}{$\begin{array}{l}\text { Production in } \\
\text { KG }\end{array}$} & Paddy & Paddy & Wheat & Wheat & Maize. & Maize & Millet & Millet \\
& HH no. & $\%$ & HH no. & $\%$ & HH no. & $\%$ & HH.no. & $\%$ \\
\hline Less than 100 & 52 & 26 & 100 & 50 & 57 & 28 & 57 & 28 \\
\hline $101-500$ & 50 & 25 & 82 & 41 & 98 & 49 & 98 & 49 \\
\hline $501-1000$ & 43 & 21 & 14 & 7 & 34 & 17 & 34 & 17 \\
\hline $1001-1500$ & 27 & 13 & 2 & 1 & 4 & 2 & 4 & 2 \\
\hline $1501-2000$ & 13 & 6 & 1 & 0 & 1 & 0 & 1 & 0 \\
\hline 2000 above & 17 & 8 & 3 & 1 & 8 & 4 & 8 & 4 \\
\hline
\end{tabular}

Source: Field survey, 2014

The differentiating in production amountin different VDC was due to the physiographic condition. The Melamchi River flows through Melamchi VDC and lower belt of Ichok VDC whereas; Duwachour and Helambu lie in the mountain ridges. The land where irrigation is available throughout the year, the trend of cultivating paddy is twice in a year. Summer rice is planted in March/April and harvested in July/August. Similarly, winter rice is planted in June/July and harvested in November/December.

Table 4: Total cash crops produced in $\mathrm{kg}$

\begin{tabular}{|l|r|r|r|r|r|r|}
\hline VDC/Cash Crops (kg) & Potato & Mustard & Vegetables & Cardamom & Ginger & Apple \\
\hline Melamchi & 30480 & 635 & 8820 & 0 & 0 & 0 \\
\hline Ichok & 16770 & 805 & 3000 & 0 & 0 & 0 \\
\hline Duwachour & 1750 & 300 & 100 & 20 & 125 & 0 \\
\hline Helambu & 8290 & 411 & 1100 & 541 & & 300 \\
\hline Total & 57290 & 2151 & 13020 & 561 & 125 & 300 \\
\hline
\end{tabular}

Source: Filed Survey, 2014

It is clear that more production in Melamchi and Ichok VDC is because of 84 percent and 72 percent of household respectively having access to canal for irrigation. Cereal crops are the major food for the subsistence needs of family but people have been involved in commercial farming specially vegetables farming. Households where have the road 
access are involved in seasonal and off seasonal vegetable farming as well as high value cash crop such as cardamom, ginger and apple where they have access to market for sale (Table 4). Development of road networks (Melamchi- Helambu Road and other rural roads) and expansion of market centers have played a key role on changing the agricultural pattern. Such case was observed in eastern hill of Nepal after construction of road in 1987-88 especially in Dhankuta when it was connected with Tarai (Koirala, 2008; Khatiwada, 2010). In this area also, Melamchi and Ichok VDCs are characterized by better road facilities. As a result, potatoes and other green vegetables are cultivated more in these two accessible VDCs in comparison to Duwachour and Helambu. Mustard is grown in all VDCs but most of the production is just for household consumption. Recently, people are attracted towards planting large cardamom as well in Duwachour and Helambu VDCs. After some years, it is expected that they might earn a lot of cash income from cardamom. Due to the favorable condition with high elevation some houses have planted apple trees in Helambu VDC.

\section{Livelihood dependent on livestock}

The livestock is another integral aspect of rural livelihood in this area. It is a multi-related household activity, which is second important economic activity of families dependent on agriculture. Animal husbandry is the huge source of income and a major capital investment. It is placed second only after land holding in the rural setting. Possession of land or livestock defines and reflects both wealth and social status of people. The household with livestock have their daily activity revolved around their animals, from feeding fodders, cleaning their sheds, milking, to grazing, etc. Although, every member indirectly involve for raising animals, household head or some dedicated family member is in-charge of looking after the cattle in their house. In few household people are hired from outside for animal husbandry. Cattle are mostly used for ploughing their farmland. Animals waste has been used as a fertilizer in agricultural field. Similarly, animals are the vital source of nutrition providers-milk, meat, etc. for the families.

Table 5: Distribution of livestock in Melamchi valley.

\begin{tabular}{|l|r|r|r|r|r|r|r|r|r|}
\hline \multirow{2}{*}{ Categories } & \multicolumn{3}{|c|}{ Melamchi } & \multicolumn{3}{|r|}{ Ichok } & \multicolumn{2}{|r|}{ Duwachour } & \multicolumn{2}{|r|}{ Helambu } & \multirow{2}{*}{ Total } \\
\cline { 2 - 10 } & HH & Number & HH & Number & HH & Number & HH & Number & \\
\hline Cattle & 8 & 10 & 14 & 26 & 20 & 46 & 17 & 36 & 118 \\
\hline Buffaloes & 20 & 33 & 26 & 45 & 36 & 52 & 25 & 52 & 182 \\
\hline Goat & 16 & 60 & 24 & 73 & 33 & 124 & & & 257 \\
\hline Chicken & 12 & 893 & 14 & 2045 & 17 & 388 & 11 & 55 & 3381 \\
\hline Total & & 996 & & 2189 & & 610 & & 143 & 3938 \\
\hline
\end{tabular}

Source: Field Survey, 2014 
In an average, there are 2 to 3 animals (excluding poultry) in surveyed household (Table 5). Livestock is the medium of earning cash income in rural villages. People are engaged in business activity by starting poultry farm. The establishment of dairy has secured the market for milk. Earning from the animal husbandry is the major source in people's income in the valley. The similar situation was even found in Rasuwa district, one of the mountain areas of Nepal where earning from livestock sector is important source of livelihood. Table 6 shows the income from animal and animal products in four VDCs of Melamchi Valley.

Table 6: Income from animal husbandry.

\begin{tabular}{|l|c|r|r|}
\hline SN & VDC & Yearly income (NRs) & \multicolumn{1}{|c|}{ Percent } \\
\hline 1 & Melamchi & 2805300 & 34.82 \\
\hline 2 & Ichok & 2761800 & 34.28 \\
\hline 3 & Duwachour & 1683500 & 20.90 \\
\hline 4 & Helambu & 805550 & 10.00 \\
\hline Total & & 8056150 & 100.00 \\
\hline
\end{tabular}

Source: Field Survey, 2014

A total annual income from animal husbandry in surveyed household is more than Rs 8 million. Melamchi and Ichok each earn about Rs 3 million whereas Duwachour and Helambu earn Rs 1.5 million and around 1 million per annum respectively. Average household income from livestock is Rs 57,000, Rs 55,000, Rs 32,000 and 15,000 in Melamchi, Ichok, Duwachour and Helambu VDCs respectively. The three VDCs i.e. Melamchi, Ichok and Duwachour are about in same condition for livestock raising but Helambu is not in same position. Recently, poultry farming for commercial purpose has been started in Duwachour. Returnee migrants from foreign labor from Gulf Countries have started commercial poultry farming together with vegetable farming.

\section{Business: An unconventional rural livelihood}

Business has become another activity that rural people rely upon nowadays. People need various kinds of goods for household uses as well as inputs for farming such as fertilizers, pesticides, hybrid seeds etc. The demand of such farming goods had inspired people to open shops to sell these goods in the rural areas together with collection center for food grains, dairy, grocery shops are other business activity people have opted. As urbanization has taken place slowly in market centers; hospitality, construction and electronic business have also been grown slowly. About 7 percent of total population (11 percent of economically active population) are involved in business in respondent 
household. Being a market center, Melamchi VDC has highest percentage of business enterpreneurs (36 percent of economically active population), whereas, rest 3 VDCs have 6 percent each of economically active population (Table 1). Now-a-days, petty business has gradually become popular in the rural areas in Nepal. A study by Rai (2009) in Arun Valley of eastern Nepal and study by Rajbansi (2010) in the peripheral areas of Kathmandu valley have suggested that petty business in the rural areas of Nepal has also become an important base of livelihood in the recent days. Local products such as liquor (local beer and alcohol),grain, vegetables, fruits, livestock (goat, pig, chicken etc.), livestock products (ghee, milk, meat) and merchandise goods are sold in the local market by petty business enterpreneurs.

\section{Service sector}

People involving in service sector are very less in number. However, it is the major source of income for some families. Basically, Brahmin, Kshetri and Newar people involve in service sector since they were forward in education. School teacher, army, police and NGOs are some of the service holders in this valley. Of the total, 17 percent of economically active people involve in service sector in Melamchi VDC, whereas, 8 , 5 and 1 percent of economically active population of Ichok, Duwachor and Helambu are involved in service sector respectively (Table 1).

\section{Foreign employment and remittance: An important source of livelihood}

Nepalese migrants used to leave the country for foreign employment with various motives long back ago. The demand for Nepalese labor abroad has relieved the unemployment problem to some extent and the remitted fund has contributed to reduce the poverty level of the country to a larger extent (CBS, 2004). Among the various uses of remitted fund vary by reducing poverty, creating economic security and enhancing social status within the household and the community. Remittances have been playing pivotal role by relaxing foreign exchange constraint, increasing contribution to GDP and strengthening the balance of payment situation of the country (Shrestha, 2009).

Remittance has become an integral livelihood component in Melamchi Valley. According to the field survey 12 percent of economically active population was remittance earner. Of the total sampled household 57 percent worked in Gulf Countries, 24 percent in India, 10 percent in Malaysia, 4 percent each in Japan/Korea and Europe together with 1 percent in the USA (Table 7). 
Table 7: Destination countries and number of migrant worker

\begin{tabular}{|l|r|r|r|r|}
\hline Country & Melamchi & Ichok & Duwachour & Helambu \\
\hline USA & & & & 1 \\
\hline Europe & & & & 3 \\
\hline Korea/Japan & & 2 & & 1 \\
\hline India & & 2 & 2 & 12 \\
\hline Malaysia & 1 & 4 & 1 & 1 \\
\hline Gulf Countries & 3 & 13 & 14 & 8 \\
\hline Total & 4 & 21 & 17 & 26 \\
\hline
\end{tabular}

Source: Field Survey, 2014

Gulf Countries (58\%), Europe (14\%) are the major remittance supplier nations in surveyed household. Similarly, Malaysia, India and Japan/Korea contributed equal ( $9 \%$ each) in total remittance. The USA contributed $1 \%$ in remittance inflow (Table 8 ). Total inflow of remittance from the USA, Europe and Japan/Korea is low but individual earning is high there. As informed by the participants of FGDs, so in the recent days, educated youths are attracted for employment towards the countries where earning level is high,.

Table 8: Inflow of Remittance

\begin{tabular}{|l|r|r|r|r|r|r|r|}
\hline VDC & $\begin{array}{r}\text { Gulf } \\
\text { Countries }\end{array}$ & Malaysia & India & $\begin{array}{r}\text { Korea/ } \\
\text { Japan }\end{array}$ & Europe & USA & Total \\
\hline Melamchi & 830000 & 180000 & & & & & 1010000 \\
\hline Ichok & 4270000 & 1320000 & 200000 & 1300000 & & & 7090000 \\
\hline Duwachour & 2646000 & 200000 & 280000 & & & & 3126000 \\
\hline Helambu & 4070000 & 160000 & 1279000 & 600000 & 2900000 & 240000 & 9249000 \\
\hline Total & 11816000 & 1860000 & 1759000 & 1900000 & 2900000 & 240000 & 20475000 \\
\hline
\end{tabular}

Source: Field Survey, 2014

Not only in Melamchi Valley, but also most of the rural areas in Nepal, remittance has become main base of livelihood in these days. Studies carried out by Koirala (2010) in eastern hill district Dhankuta found more than one-third of the total household dependent upon remittance for livelihoods. In the same way, in rural areas of Dolakha, almost half of the surveyed households are belonged to remittance based livelihood (Koirala, 2011). 


\section{Wage labor}

Families who does not have proper source of income are basically engaged in wage labor. In the respondent household 7 percent of the total economically active population are wage labors in both agricultural and non-agricultural tasks. But most of the wage labors are engaged in non-agricultural sector. During the planting and harvesting season people work as agricultural labor in own field and in Parma system for short time and during other seasons people get them engaged in different works such as construction, porters, mason, carpenters, etc. in the village and beyond. The earning for the daily work helps to run their livelihood. The under constructing projects such as Melamchi Drinking Water Project, various hydro projects running in the Bhote Koshi River and development of road networking in the village have also provided adequate opportunities for wage labors in the rural areas of Sindhupalchok district.

\section{Conclusions}

Livelihood strategy is basically a process of adapting the socio-economic activity according to the nature with available resources in particular time and space. Agricultural activity, especially cereal crop production is the vital activity of people in which they spent their more resources and time; however, it merely fulfills their increasing household demand. In order to accomplish the requirement for living, a sizable number of people in Melamchi village are engaged in trade and business. Road connectivity and growth as market center has created such environment to choose the new strategies in the village. There is not sole dependence on traditional agriculture; people involve in more market oriented products like vegetable farming, cash crops, and poultry farming. Returnee migrants from foreign labor involve in these activities. Such activities have provided self-employment opportunities to the people of this area. Infrastructure along the Melamchi corridor has created new job opportunities, people in lower elevation has been benefited from these developments. Moreover, there is a massive trend of migration to foreign land in order to earn better livelihood. It is interesting to note that people generally from higher elevation are huge remittance earner since the flow of migrants is high in the upper settlements. The growth of market center to adjoining villages has created opportunities for skilled and unskilled human resource in the informal sectors such as carpenter, mason, construction labor, porter, helper, etc. which are known as important source of livelihood in this area in the recent days.

\section{References}

Bhattarai, M. P. (2008). Livelihood strategies of the street vendors. A comparative study of mobile and static vendors in Kathmandu Metropolis. Unpublished Master's Thesis in Geography, Kathmandu: Tribhuvan University. 
Madhu Krishna Neupane; and Dhyanendra Bahadur Rai / The Geographical Journal of Nepal Vol. 11: 113-126, 2018

Bishop, B. (1990). Karnali under stress: Livelihood stratigies and seasonal rhythms in changing Nepal Himalaya. Chicago: University of Chicago.

CBS (2004). Nepal living standards survey-2003/04 (Statistical report vol. II). Kathmandu: Central Bureau of Statistics (CBS), National Planning Secretariat, HMG, Nepal.

Chambers, R., \& Conway, G. (1991). Sustainable rural livelihoods: Practical concepts for the $21^{\text {st }}$ Century. IDS Discussion Paper 296. University of Sussex: Institute for Development Studies.

Chhetri, R. B. (2006). Changing environments and livelihoods: Adaptation of the Jalari People in the Pokhara Valley. In R. B. Chhetri (ed.), Contribution to Nepalese Studies (Sp. issue), 33: 81-109.

Ellis, F. (2000). Rural livelihoods and diversity in developing countries. New York: Oxford University Press.

Khatiwada, S. P. (2010). Continuity and change of livelihood activities in the Tankhuwa Khola Watershed in Eastern Hills , Nepal. In: P. K. Pradhan, B. P. Subedi and N. R. Khanal (eds), Environmental, Livelihood and Micro-Enterprises. Kathmandu: Central Department of Geography, Tribhuvan University, Nepal.

Khatiwada, S. P. (2011). Persistent change in livelihoods in Bhirgaun, Eastern Nepal. The Geographical Journal of Nepal, 8: 73-8.

Koirala, H. L. (2006). Livelihood pattern, adaptive strategy and sustainability of communities in Southern Arun Valley of Nepal Himalayas. Unpublished PhD. dissertation, University of Gauhati. India.

Koirala, H. L. (2010). Changing livelihood strategies in the hills and mountains: Experiences from Nepal. In (eds) P. K. Pradhan, B. P. Subedi and N. R. Khanal. Environment, livelihood and micro enterprises. Kathmandu: Central Department of Geography, TU.

Neupane, K. (2017). Livelihood strategies of the people living in Melamchi watershed area. Master's thesis, Central Department of Geography, TU, Kathmandu, Nepal.

Rai, D. B. (2009). Livelihood patterns of Majhi and Kumal Communities in the Arun Valley, Eastern Nepal.The Geographical Journal of Nepal, 7: 7-14.

Rai, D. B. (2011). Livelihood Strategies of a Rural Community: A Case of Thani in Chhathali, Environmental Resources and Cultural Landscape: Understanding 
Changing, Spatial Organization of Bhimeshwor Dolakha. Kathmandu: Central Department of Geography, T.U., Kirtipur.

Rajbansi, A. (2010). Livelihood diversification in a peri-urban area of Nepal: A survival strategy of marginal communities. In: P. K. Pradhan, B. P. Subedi and N. R. Khanal (eds), Environmental, Livelihood and Micro-Enterprises. Kathmandu: Central Department of Geography: Tribhuvan University, Nepal.

Sharma, S. R., Upreti, B. R., \& Muller-Boker, U. (2014). Negotiating access to land in Nepal, Journal of Contemporary Asia, 44 (3):521-539.

Shrestha, P. (2009). Foreign employment and remittance in Nepal. Economic Journal of Nepal, 32(1): 46-60.

Subedi, B. P., \& Pandey, R. (2002). Livelihood strategies of Rai communities in Arun Valley: Continuity and change.Vegetation and Society: Their interaction in Himalayas, T.U. Nepal and University of Bergen, Norway.

Subedi, B. P., (1993). Continuity and change in population movement: From inside a rural Nepali community. Unpublished PhD dissertation, University of Hawaii, Department of Geography. 